IZA DP No. 5988

Creativity and the Family Tree:

Human Capital Endowments and the

Propensity of Entrepreneurs to Patent

Albert N. Link

Christopher J. Ruhm

September 2011 


\title{
Creativity and the Family Tree: Human Capital Endowments and the Propensity of Entrepreneurs to Patent
}

\author{
Albert N. Link \\ University of North Carolina at Greensboro
}

Christopher J. Ruhm

University of Virginia,

NBER and IZA

Discussion Paper No. 5988

September 2011

\author{
IZA \\ P.O. Box 7240 \\ 53072 Bonn \\ Germany \\ Phone: +49-228-3894-0 \\ Fax: +49-228-3894-180 \\ E-mail: iza@iza.org
}

\begin{abstract}
Any opinions expressed here are those of the author(s) and not those of IZA. Research published in this series may include views on policy, but the institute itself takes no institutional policy positions.

The Institute for the Study of Labor (IZA) in Bonn is a local and virtual international research center and a place of communication between science, politics and business. IZA is an independent nonprofit organization supported by Deutsche Post Foundation. The center is associated with the University of Bonn and offers a stimulating research environment through its international network, workshops and conferences, data service, project support, research visits and doctoral program. IZA engages in (i) original and internationally competitive research in all fields of labor economics, (ii) development of policy concepts, and (iii) dissemination of research results and concepts to the interested public.
\end{abstract}

IZA Discussion Papers often represent preliminary work and are circulated to encourage discussion. Citation of such a paper should account for its provisional character. A revised version may be available directly from the author. 
IZA Discussion Paper No. 5988

September 2011

\section{ABSTRACT \\ Creativity and the Family Tree: \\ Human Capital Endowments and the Propensity of Entrepreneurs to Patent}

In this paper we show that the patenting behavior of creative entrepreneurs is correlated with the patenting behavior of their fathers, which we refer to as a source of the entrepreneurs' human capital endowments. Our argument for this relationship follows from established theories of developmental creativity, and our empirical analysis is based on survey data collected from MIT's Technology Review winners.

JEL Classification: J24, O31

Keywords: patents, entrepreneurship, human capital endowments

Corresponding author:

Albert N. Link

Department of Economics

University of North Carolina at Greensboro

Greensboro, NC 27401

USA

E-mail:anlink@uncg.edu 


\section{Creativity and the Family Tree:}

\section{Human Capital Endowments and the Propensity of Entrepreneurs to Patent}

\section{Introduction}

The propensity to patent by firms and entrepreneurs is related to the external and internal environment of each. The environment surrounding firms consists externally of their market structure and internally of their investments in research and development (R\&D), among other things (Cohen 2010). That surrounding entrepreneurs also consists externally of their market environment and internally of both their financial ability (own or that of alternative investors) to movetheir technology to a market innovation and their incentive structure (Siegel et al. 2003).

Surprisingly, this literature has ignored humancapital endowments when comparing the propensity to patent across entrepreneurs. ${ }^{1}$ Link and Ruhm (2011) focused on investments in human capital and showed that prior business education/experience is a correlate with patenting. This paper extends the study of patenting by focusing on the developmentally-acquired creativity of the entrepreneur.

In Section II we posit a model of human capital endowments, obtained through observing parental behavior, and one's propensity to patent; we describe our database; and we present our empirical findings. Concluding remarks are in Section III.

\section{The Propensity to Patent}

\subsection{An Empirical Model}

Creativity is "the interaction among aptitude, process, and environment by which an individual or group produces a perceptible product that is both novel and useful." (Plucker et al. 2004, p.90). Kaufman and Sternberg (2007) discuss creativity in several dimensions, often referred to as "4-Ps." The "Ps" are the creative person, product, process, and place (i.e., environment).

\footnotetext{
${ }^{1}$ Nicolaou et al. (2008) argued that genetic factors be considered for why individuals engage in entrepreneurial activity. Relatedly, Bates (1985) showed a positive relationship between human capital endowments and minority enterprise profitability.
} 
Thus, a creative person can produce, through a creative process, a creative product; and it follows that the creative person and his/her process can be influenced by place.

Creativity, as reflected through innovativeness, is also a characteristic of an entrepreneur(Hébert and Link 2009); and patenting is a purposeful activity motivated to protect intellectual property (Sichelman and Graham 2010). Generally, a requirement for a patent is that the invention isnovel, useful, and non-obvious (USPTO 2011).

Our frameworkstems from developmental theories of creativity. Goertzel and Goertzel (1976),Helson(1999),and others argued that developmental experiences of individuals, including parental guidance and family structure, are correlated with the demonstrated creativeness of individuals. The roots of the background of individuals establish the trajectory for their creative development (Kozbelt et al. 2010). ${ }^{2}$

Based on this argument,we hypothesize that the propensity of a creative individual (i) to patent is related to the same behavior of his/her parents:

(1) $\quad$ Patent $_{i}=\mathrm{F}\left(\mathbf{X}_{i}+u_{i}>0\right)$

wherePatentmeasures the propensity of an individual to patent, $\mathbf{X a}$ vector of parental patenting activity and other characteristics, and $u_{i} \sim \mathrm{N}(0,1)$.

We estimated equation (1) using a rich and previously unexamined database of international inventors, as acknowledged by MIT's Technology Review.

\subsection{Technology Review Database}

To commemorate the $100^{\text {th }}$ year of publication of MIT's innovation magazine, Technology Review(TR), 100 international inventors (under age 35 at nomination) from universities, businesses, and government laboratories, who have the potential to make major technology contributions in the decades ahead, were identified in the November/December 1999 issue of the

\footnotetext{
${ }^{2}$ Self-employed entrepreneurs often have fathers who were self-employed (Shane 2003).
} 
Review (Benditt 1999). TR100 inventors received this distinction in 2002, 2003, and 2004. In 2005 , and thereafter, the TR100 became the TR35. ${ }^{3}$

All TR winners, arguably among the most inventive young individuals from 1999 through 2009(thus, not representative of all creative entrepreneurs)are the population for our surveybased study. We obtained e-mail addresses and were able to contact 341 of the 575 winners. Sixty-three, or 18.5 percent, of those returned surveys. ${ }^{4}$ See Table 1.

The specification of equation (1) is parsimonious owing to limited survey information and to the relatively homogenous nature of $T R$ winners. For example, 83 percent holds a terminal degree (i.e., $\mathrm{PhD}, \mathrm{MD}$, or JD)Nominees must be under 35; the age range in Table 3 is 26 to 35 .

\subsection{Empirical Findings}

The variables used to estimate equation (1) are defined and descriptive statisticsare in Table 2.

We estimated equation (1) using a two-part model.Regarding the probit results in column (1) of Table 3 for the full survey sample of $n=63$, creative entrepreneurs with fathers who patented are nearly 26 percentage points more likely to patent themselves compared to a similarly creative entrepreneur whose father did not patent, ceteris paribus. Also, those of Asian descent and those with a graduate degree in science or engineering are also relatively more likely to patent than other creative entrepreneurs. Finally, males are more likely to patent than females but the difference does not reach statistical significance $(\mathrm{p} \text {-value }=0.12)^{5}$

The second part of our estimation involves identifying correlates with the natural log of the number of patents received conditional on patenting. As seen in column (2) for the sample of $\mathrm{n}=29$ who patented, those with a patenting father patent more, ceteris paribus. There is also evidence that age is a factor in determining the number of patents received rather than the per

\footnotetext{
${ }^{3}$ This change coincided with a new editor at Technology Review.

${ }^{4}$ This response rate is on par with others innovation studies. The response rate for the National Research Council's (NRC's) Congressional mandated study of NASA Small Business Innovation Research award recipient firms was $23 \%$.

${ }^{5}$ Baer and Kaufman (2008) argued that there are no gender differences in the creativity of individuals, based on traditional tools for measuring creativity.
} 
sepropensity to patent, but this finding may only represent the fact that receipt of a patent is time intensive. And, nationality is not significant among those who patent, but field of study is.

Finally, in column (3), we treated patenting as a count process. The negative binomial results confirm the positive predicted effect of one's father having patented. Males and Asians also have higher patent counts, but field of study is no longer relevant reflecting the previous evidence that scientists and engineers are more likely to patent but in smaller numbers among those who do so.

Equation (1) was also estimated as a probit model with control for survey response; that is, it was estimated as a maximum likelihood model with selection. The model for non-response was estimated as a function of the award year, Year, under the argument that the earlier in time the award the less likely the awardee would respond to the survey, and the probit results confirmed this. However, when estimated simultaneously with the probability of patenting model, the correlation between the error terms was not significant. Separately, we estimated the model underlying the results in column (1) of Table 3 with Year and a regressor. The estimated coefficient on Year was not significant thus supporting the conclusion that this variable could reasonably be excluded from the patenting probit model.

\section{Concluding Observations}

We caution against generalizing from our patent-specific findings that observed parental behavior is related to other dimensions of entrepreneurial creativity. Our sample of $T R$ winners is unique, and our economic analysis is exploratory in structure and scope. Nevertheless, our findings might suggest that human capital endowments be considered in future studies of innovative behavior. 
Table 1

Data Reduction Process

\begin{tabular}{rrrrr}
\hline Year & Winners & $\begin{array}{r}\text { Number of } \\
\text { Surveys }\end{array}$ & Responses & $\begin{array}{r}\text { Response } \\
\text { Rate }\end{array}$ \\
\hline 1999 & 100 & 64 & 8 & $12.5 \%$ \\
2002 & 100 & 53 & 9 & $17.0 \%$ \\
2003 & 100 & 55 & 8 & $14.5 \%$ \\
2004 & 100 & 58 & 9 & $15.5 \%$ \\
2005 & 35 & 22 & 6 & $27.3 \%$ \\
2006 & 35 & 22 & 4 & $18.2 \%$ \\
2007 & 35 & 19 & 5 & $26.3 \%$ \\
2008 & 24 & 5 & $20.8 \%$ \\
2009 & 35 & $\underline{24}$ & $\underline{9}$ & $37.5 \%$ \\
& $\underline{35}$ & 341 & 63 & $18.5 \%$ \\
\hline
\end{tabular}


Table 2

Definition and Descriptive Statistics for Variables Relevant to TR Entrepreneur (n=63)

\begin{tabular}{|c|c|c|c|c|}
\hline Variable & Definition & Mean & Std. Dev. & Range \\
\hline \multicolumn{5}{|l|}{ Dependent } \\
\hline Patent & $\begin{array}{l}1 \text { if } \geq 1 \text { patent granted through } 2009,0 \\
\text { otherwise }\end{array}$ & 0.4603 & 0.5024 & $0 / 1$ \\
\hline NoPat & Number of patents granted through 2009 & 1.9048 & 4.1648 & $0-20$ \\
\hline \multicolumn{5}{|l|}{ Independent } \\
\hline DadPatent & $\begin{array}{l}1 \text { if the father granted } \geq 1 \text { patent through } 2009 \text {, } \\
0 \text { otherwise }\end{array}$ & 0.2381 & 0.4293 & $0 / 1$ \\
\hline Female & 1 if female, 0 if male & 0.3810 & 0.4895 & $0 / 1$ \\
\hline Age & Age when $T R$ award announced & 31.3492 & 2.4832 & $26-35^{\mathrm{a}}$ \\
\hline Asian & 1 if $T R$ winner is Asian, 0 otherwise & 0.2222 & 0.4191 & $0 / 1$ \\
\hline Science $^{\mathrm{b}}$ & $\begin{array}{l}1 \text { if field of study in the basic sciences, } 0 \\
\text { otherwise }\end{array}$ & 0.3810 & 0.4895 & $0 / 1$ \\
\hline Engineer & 1 if field of study in engineering, 0 otherwise & 0.3333 & 0.4752 & $0 / 1$ \\
\hline Year & Year of award & 2004.444 & 3.1201 & 1999-2009 \\
\hline
\end{tabular}

Note:

None of the TR winner's mothers held a patent.

a SeveralTR winners turned 35 by the time of the award.

${ }^{\mathrm{b}}$ Non-science and non-engineering fields of study include: art, business, history, medicine, and philosophy. 
Table 3

Estimation of Equation (1)

\begin{tabular}{|c|c|c|c|}
\hline Variable & $\begin{array}{r}(1) \\
\text { Dep. Var.=Patent } \\
\text { Estimation: Probit }\end{array}$ & $\begin{array}{r}(2) \\
\text { Dep. Var.=InNoPat } \\
\text { Estimation: OLS }\end{array}$ & $\begin{array}{r}(3) \\
\text { Dep. Var.=NoPat } \\
\text { Estimation: Negative } \\
\text { Binomial }\end{array}$ \\
\hline \multirow[t]{2}{*}{ DadPatent } & 0.2555 & 0.7186 & 3.5061 \\
\hline & $(0.1322) *$ & $(0.3053) * *$ & $(1.7337)^{* *}$ \\
\hline \multirow[t]{2}{*}{ Female } & -1.6901 & -0.1190 & -0.8841 \\
\hline & $(0.1093)$ & $(0.3013)$ & $(0.5132)^{*}$ \\
\hline \multirow[t]{2}{*}{ Age } & 0.0086 & 0.1085 & 0.2767 \\
\hline & $(0.0212)$ & $(0.0608)^{*}$ & $(0.1866)$ \\
\hline \multirow[t]{2}{*}{ Asian } & 0.4949 & 0.3920 & 3.1034 \\
\hline & $(0.1022)^{* * *}$ & $(0.2875)$ & $(1.1169)^{* * *}$ \\
\hline \multirow[t]{2}{*}{ Science } & 0.3267 & -0.8572 & 0.6965 \\
\hline & $(0.1317)^{* *}$ & $(0.4019)^{* *}$ & (1.123) \\
\hline \multirow[t]{2}{*}{ Engineer } & 0.2805 & -1.2783 & -0.3166 \\
\hline & $(0.1453)^{*}$ & $(0.4234)^{* * *}$ & $(0.7830)^{*}$ \\
\hline constant & -- & $\begin{array}{r}-2.0630 \\
(1.9546)\end{array}$ & - \\
\hline $\mathrm{n}$ & 63 & 29 & 63 \\
\hline LR/Wald $\chi^{2}$ & 23.56 & -- & 64.25 \\
\hline Pseudo $\mathrm{R}^{2}$ & 0.2710 & -- & -- \\
\hline Log pseudo-likelihood & -31.69 & -- & -90.58 \\
\hline $\mathrm{R}^{2}$ & -- & 0.6193 & -- \\
\hline F-Statistic & -- & 5.96 & -- \\
\hline
\end{tabular}

Note: Average marginal effects are displayed in columns (1) and (3), regression coefficients in column (2).

*significant at 0.10 level, ${ }^{* *}$ significant at 0.05 level, ${ }^{* * *}$ significant at 0.01 level. 


\section{References}

Baer, J., Kaufman, J.C.,2008. Gender differences in creativity. Journal of Creative Behavior.42, 75-106.

Bates, T., 1985.Entrepreneur human capital endowments and minority business viability.Journal of Human Resources. 20,540-554

Benditt, J., 1999. 100 hot zones. Technology Review. November/December, 12.

Cohen, W.M., 2010. Fifty years of empirical studies of innovative activity and performance, in Hall B.H., Rosenberg, N. (Eds.), Handbook of the Economics of Innovation. North-Holland, Amsterdam.

Goertzel, V., Goertzel, M.G., 1976.Cradles of Eminence.Little Brown: Boston.

Hébert, R.F., Link, A.N., 2009. A History of Entrepreneurship. London, Routledge.

Helson, R., 1999. A longitudinal study of creative personality in women.Creativity Research Journal. 12, 89-101.

Kaufman, J.C., Sternberg, R.J., 2007. Resource review: creativity. Change. 39, 55-58.

Kozbelt, A., Beghetto, R.A., Runco, M.A., 2010. Theories of creativity, in Kauffman, J.C., Sternberg, R.J. (Eds.), The Cambridge Handbook of Creativity. Cambridge, Cambridge University Press.

Link, A.N., Ruhm, C.J., 2011. Public knowledge, private knowledge: the intellectual capital of entrepreneurs. Small Business Economics. 36,1-14.

National Research Council, 2009.An Assessment of the Small Business Innovation ResearchProgram at the National Aeronautics and Space Administration. Washington, DC: National Academies Press.

Nicolaou, N., Shane, S., Cherkas, L., Hunkin, J., Spector, T.D., 2008. Is the tendency to engage in entrepreneurship genetic? Management Science. 54, 167-179.

Plucker, J.A., Beghetto, R.A., Dow, G.T., 2004. Why isn't creativity more important to educational psychologists? Potential, pitfalls, and future directions in creativity research.Educational Psychology. 39, 83-96.

Shane, S., 2003. A General Theory of Entrepreneurship: The Individual - Opportunity Nexus. Cheltenham, UK: Edward Elgar. 
Sichelman, T., Graham, S.H.G., 2010. Patenting by entrepreneurs: an empirical study.Michigan Telecommunication Technology Law Review.17, 111-180.

Siegel, D.S., Waldman, D., Link, A.N., 2003. Assessing the impact of organizational practices on the relative productivity of university technology transfer offices: an exploratory study.Research Policy. 32, 27-48.

United States Patent and Trademark Office, 2011. What can and cannot be patented. $<$ http://www.uspto.gov/inventors/patents.jsp $>$. 